\title{
Spectrum and Antibiogram of Bacteria Isolated from Commercially Available Stockfish in Eke-Awka Market, Anambra Nigeria
}

\section{Malachy C Ugwu*, Ebube Ofoegbu and Kene C Ezejiegu}

Department of Pharmaceutical Microbiology and Biotechnology, Faculty of

Pharmaceutical Sciences, Nnamdi Azikiwe University, Awka Nigeria

*Corresponding Author: Malachy C Ugwu, Department of Pharmaceutical Microbiology and Biotechnology, Faculty of Pharmaceutical Sciences, Nnamdi Azikiwe University, Awka Nigeria.
Received: June 15, 2020

Published: September 16, 2020

(C) All rights are reserved by Malachy $\mathbf{C}$ Ugwu., et al.

\section{Abstract}

Background: Food borne infections and diseases remain a major cause of morbidity and mortality, particularly among poor/ developing countries. Food products play significant role in the transfer of antibiotic resistance. There is increasing evidence of the use of antibiotics in fish rearing as growth promoters or curative agents and this could promote antibiotic selective pressure which results in emergence of resistant organisms in these sea foods. This study is aimed at isolating and determining the spectrum and antibiogram of bacteria isolated from commercially available stock fishes in eke Awka market.

Method: The isolated samples were obtained from randomly selected samples of stock fishes using pour plate method and confirmed with the help of microscopy and biochemical test. The antibiogram of the isolates were examined following Clinical and Laboratory Standard Institute breakpoints.

Results: A total of 70 samples of stock fishes were collected from the market. Staphylococcus aureus was the most contaminant $(45.7 \%)$ in the samples, followed by Klebsiella pneumoniae (41.1\%), Bacillus subtilis (30\%), Escherichia coli (15.7\%), Salmonella typhi (5.7\%) and Pseudomonas aeruginosa (4.3\%). The isolates showed resistance to most of antibiotics used. Gentamicin and Ofloxacin had appreciable activity against all Gram positive isolated bacteria while Gentamicin and Nitrofurantoin having activity against some Gram negative bacteria.

Conclusion: The study confirmed the presence of antibiotics-resistant bacteria in stock fishes, making it a potential public health threat. This calls for improved hygienic practices among the fish vendors and there should be rational use of antibiotics in fish farming.

Keywords: Antibiogram; Bacteria Isolates; Stock Fishes; Resistance; Awka

\section{Introduction}

Fishes as food are important component of our diet, irrespective of age, economic status, religion and educational background in Nigeria [1]. The affordability of fish and fish products, in addition to its nutritional provisions such as animal proteins, poly-saturated fatty acids and micronutrients makes fishes one of the major dietary components and of high commercial considerations [2]. Fishes both in their natural habitat or when reared are constantly exposed to numerous microbes [3]. These microbes, as parasites create some damages in fish farms and the diseases caused by microbes are accountable for heavy loss [4]. They ultimately could cause fish -borne diseases if not properly processed.

There has been an increase in the use of antibiotics (approved or unapproved) for fish rearing, either as growth promoters or as curative agents $[5,6]$. The use of these antibiotics in fishery is a serious concern to public health [7] with regards to serving as potential sources for spread of microbial infection and resistance. Several 
pathogenic organisms such as Staphylococcus aureus, Escherichia coli, Salmonella spp, Pseudomonas spp, Serratiaspp, Salmonella spp, Klebsiella spp, Shigella spp and Bacillus spp have been isolated in fishes in Nigeria [1,8].

Antibiogram study is an important tool for antibiotic resistance monitoring and provides a review on the resistance pattern over a period. It also aids in evidence-based selection of antibiotics for empirical treatment of infections in an area [9]. Several studies have evaluated the sensitivity of microorganism isolated from fresh water fish, smoked and frozen fishes in different parts of Nigeria $[8,10,11]$. However, there is paucity of information on the antibiotic sensitivity of microorganisms found in stock fishes in $\mathrm{Ni}$ geria, and in particular Eke - Awka market South-eastern Nigeria.

This study therefore was designed to determine the spectrum and antibiogram of bacterial isolates in commercially available stock fishes in Eke Awka market, Anambra State, Nigeria.

\section{Methods}

Seventy (70) randomly selected stock fish, obtained from different vendors in Eke Awka market, Awka, Anambra State, Nigeria were analyzed for bacteria contamination. The organisms growing visibly on the Petri dish were isolated, purified by sub-culturing on a fresh nutrient agar and identified by assessing their colony characteristics, Gram reaction and biochemical characteristics. The identified isolates Staphylococcus aureus, Klebsiella pneumonia, Bacillus subtilis, Escherichia coli, Salmonella typhi and Pseudomonas aeruginosa were subjected to antibiotic susceptibility test to evaluate their sensitivity and/resistance profile.

\section{Antibiogram}

Antibiotics susceptibility testing was performed using KirbyBauer disk diffusion method as recommended by Clinical Laboratory Standards Institute [12] using the Mueller-Hinton agar, and the following antimicrobials disks were tested: Ceftazidime $30 \mu \mathrm{g}$. Cefixime $5 \mu \mathrm{g}$, Ciprofloxacin $5 \mu \mathrm{g}$, Ofloxacin $5 \mu \mathrm{g}$, Gentamicin $10 \mu \mathrm{g}$, Amoxicillin/Clavulanate $30 \mu \mathrm{g}$, Nitrofurantoins $300 \mu \mathrm{g}$. The bacteria isolates were diluted in saline to obtain turbidity equivalent to 0.05 McFarland standard. Aliquots were seeded by swabbing on Mueller-Hinton agar plates, with subsequent application of the antibiotic disks. The plates were incubated at $37^{\circ} \mathrm{C}$ and interpreted via inhibition zone diameter (IZD) according to the CLSI.

\section{Results}

The samples of stock fishes collected from the market were tested to determine the spectrum and Antibiogram of some potential bacterial isolates. The isolated bacteria were identified using Gram reaction, colony characteristics and biochemical test. Table 1 shows the isolated bacterial to be Staphylococcus aureus (41.1\%), Klebsiella pneumonia (34.3\%), Bacillus subtilis (30.0\%), Escherichia coli (15.7\%), Salmonella typhi (5.7\%) and Pseudomonas aeruginosa (4.3\%). Table 2 and 3 shows the results of antibiogram of the isolates from stock fish using the disc diffusion assays. S. aureus, and B. sutilis showed a good level of sensitivity (> 70\%) to Gentamicin and Ofloxacin. While $S$. aureus had fairly good susceptibility to Cefuroxme, 43.8\% and Amoxicilli/Clavulanate, 46.9\%. Both isolates were highly resistant to Ceftazidine, Ceftriaxone and Cloxacillin.

Among the Gram negative organisms, E. coli had the best susceptibility profile than the other isolates. All Gram negative organisms

\begin{tabular}{|l|c|c|c|c|c|c|}
\hline \multicolumn{1}{|c|}{ Features } & S. aureus & K. pneumonia & B. subtilis & E. coli & S. typhi & P. aerugiosa \\
\hline Colony characteristics & $\begin{array}{c}\text { Golden yel- } \\
\text { low }\end{array}$ & $\begin{array}{c}\text { Pink mucoid } \\
\text { colonies }\end{array}$ & $\begin{array}{c}\text { Milky raised } \\
\text { large colonies }\end{array}$ & $\begin{array}{c}\text { Small circular } \\
\text { opaque colonies }\end{array}$ & $\begin{array}{c}\text { Black shinny } \\
\text { opaque colonies }\end{array}$ & $\begin{array}{c}\text { Bright green } \\
\text { colonies }\end{array}$ \\
\hline Gram character & Positive & Negative & positive & Negative & Negative & Negative \\
\hline Microscopic features & $\begin{array}{c}\text { Purple cocci } \\
\text { clusters }\end{array}$ & Short oval rod & $\begin{array}{c}\text { Slender purple } \\
\text { rod }\end{array}$ & Short red rod & $\begin{array}{c}\text { Slender rod } \\
\text { Long red slen- } \\
\text { der rod }\end{array}$ \\
\hline Catalase test & Positive & - & Positive & - & Positive & Positive \\
\hline Oxidase test & Negative & - & Positive & - & Negative & - \\
\hline Indole test & - & Negative & Positive & Positive & - \\
\hline Citrate test & - & Positive & - & Negative & - \\
\hline
\end{tabular}

Table 1: Identification features of the isolates. 
Spectrum and Antibiogram of Bacteria Isolated from Commercially Available Stockfish in Eke-Awka Market, Anambra Nigeria

\begin{tabular}{|c|c|c|c|c|c|c|}
\hline \multirow{2}{*}{ Agent } & \multicolumn{3}{|c|}{ Staphylococcus aureus } & \multicolumn{3}{c|}{ Bacillius subtilis } \\
\cline { 2 - 7 } & S (\%) & I (\%) & R (\%) & S (\%) & I (\%) & R (\%) \\
\hline CRX & 43.75 & 6.3 & $50 . .0$ & 3.0 & 1.0 & 0 \\
\hline CTZ & 0 & 0 & 100.0 & 0 & 0 & 17.0 \\
\hline AUG & 46.9 & 12.5 & 40.6 & 4.0 & 0 & 21.0 \\
\hline GEN & 93.8 & 3.1 & 3.1 & 19.0 & 2.0 & 18.0 \\
\hline CEF & 9.4 & 28.1 & 62.5 & 1.0 & 9.0 & 7.0 \\
\hline ERY & 12.5 & 21.9 & 65.6 & 5.0 & 1.0 & 20.0 \\
\hline CLOX & 6.3 & 15.6 & 78.1 & 0 & 4.0 & 5.0 \\
\hline OFX & 78.1 & 15.6 & 6.25 & 12.0 & & 0 \\
\hline
\end{tabular}

Table 2: Susceptibility profile of Gram positive isolates.

Key: S: Susceptibility; I: Intermediate; R: Resistance.

\begin{tabular}{|c|c|c|c|c|c|c|c|c|c|c|c|c|}
\hline \multirow[t]{2}{*}{ Agents } & \multicolumn{3}{|c|}{ K. pneumonia } & \multicolumn{3}{|c|}{ E. coli } & \multicolumn{3}{|c|}{ S. typhi } & \multicolumn{3}{|c|}{ P. aeruginosa } \\
\hline & $S(\%)$ & $I(\%)$ & $\mathrm{R}(\%)$ & $S(\%)$ & $I(\%)$ & $\mathbf{R}(\%)$ & $S(\%)$ & I(\%) & $\mathbf{R}(\%)$ & $S(\%)$ & I(\%) & $\mathrm{R}(\%)$ \\
\hline OFX & 17.2 & 31.0 & 51.7 & 54.5 & 18.2 & 27.3 & 0 & 0 & 100 & 33.3 & 0 & 66.6 \\
\hline AUG & 0 & 17.2 & 82.8 & 63.6 & 27.3 & 9.1 & 0 & 0 & 100 & 0 & 0 & 100 \\
\hline NIT & 10.3 & 27.6 & 62.1 & 90.9 & 9.1 & 0 & 0 & 25 & 75 & 33.3 & 33.3 & 33.3 \\
\hline $\mathrm{CPR}$ & 10.3 & 10.34 & 79.31 & 54.5 & 27.3 & 18.2 & 0 & 0 & 100 & 0 & 66.6 & 33.3 \\
\hline $\mathrm{CTZ}$ & 0 & 0 & 100 & 9.1 & 45.5 & 45.5 & 0 & 0 & 100 & 0 & 0 & 100 \\
\hline CRX & 0 & 0 & 100 & 9.1 & 45.5 & 45.5 & 0 & 0 & 100 & 0 & 0 & 100 \\
\hline GEN & 31.0 & 20.7 & 48.3 & 81.8 & 0 & 18.2 & 0 & 50 & 50 & 0 & 33.3 & 66.6 \\
\hline CXM & 0 & 0 & 100 & 0 & 9.1 & 90.9 & 0 & 0 & 100 & 0 & 0 & 100 \\
\hline
\end{tabular}

Table 3: Susceptibility profile of Gram negative isolates.

Key: Ceftazidime (CTZ); Cefuroxime (CRX); Cefixime (CXM);Ciprofloxacin (CPR); Ofloxacin (OFX);Gentamicin (GEN); Amoxycillin/Clavulanic acid (AUG); Nitrofurantoin (NIT); Ceftriaxone (CEF) Erythromycin (ERY); Cloxacillin (CLOX). S: Susceptibility; I: Intermediate; R:

had high susceptibility to Nitrofurantoin, Amoxicillin-clavulanic acid, Ofloxacin, Ciprofloxacin and Gentamicin.

\section{Discussion}

Bacteriological studies are important for actual disease diagnosis and identification of food borne pathogens. The present study was aimed at isolating and determining the Antibiogram profile of some potential organisms in stock fishes sold in Eke-Awka market Anambra Nigeria. When considered from the public health stand point, growth and presence of potential harmful microorganisms in commercially sold stock fishes is unacceptable and presents a public health threat.
The observed high occurrence of $S$. aureus in this study could be attributed to its wide range of habitats including human body parts, which may be a source of contamination for the sea food. The presence of these isolates could indicate poor hygiene during handling and processing of the fish [13]. In addition, the presence of Gram negative organisms E. coli, K. pneumonia, S. typhi, P. aeruginosa could mean potential fecal contamination of the food products. Thus, proper cooking is needed to avert the likelihood of food poisoning.

The results of the antibiotic susceptibility profiling, shows that S. aureus and B. subtilis had good sensitivity to Gentamicin and 
Ofloxacin, having the highest IZD than other antibiotics used. Moderate to total resistance was also recorded for $S$. aureus against other antibiotics. S. aureus resistance to Erythromycin may have possibly be due to production of the enzyme erythromycin esterase, enzymatic inactivation of active efflux pump as well as chemical degradation [14].

Except E. coli all the Gram negative isolates showed poor susceptibility to all antibiotics tested. E. coli showed the highest susceptibility to Gentamicin, Nitrofurantoin and Ciprofloxacin with susceptibility of $81.5 \%, 90.9 \%$, and $81.8 \%$ respectively. Gentamicin comes in parental forms as oral route/dosage form is mostly restricted by pre-systemic degradation and/or poor penetration across the gut wall [15]. The injectable forms discourage its misuse because of difficulty in its administration and its invasive nature [16] and this could explain its good inhibitory activity against some of the isolates.

\section{Conclusion}

Sea food such as stock fishes are potential vectors in the transmission of overt or opportunistic pathogenic microorganisms as well play a role in the spread of multidrug resistant bacterial strains. Isolation of bacteria especially resistant strains should raise public health concern.

\section{Bibliography}

1. Adesoji AT., et al. "Bacteriological quality and antibiogram study of bacteria from "suya" and smoked fish (Clarias gariepinus) in Dutsin-Ma, Katsina State, Nigeria". Pan African Medical Journal 33 (2019): 1-9.

2. Mohanty BP., et al. "Fish in human health and nutrition". Advances in Fish Research (2019): 189-218.

3. Olayiwola 0. "Microbiological Quality Assessment and Antibiogram of the Bacteria Isolated from Fish Feed, Oyo, SouthWest Nigeria”. Journal of Animal Science Advances 5.3 (2015): 1218.

4. Kousar R Shafi., et al. "Assessment and incidence of fish associated bacterial pathogens at hatcheries of Azad Kashmir, Pakistan". Brazilian Journal of Biology (2019): 1-8.
5. Olatoye IO and Basiru A. "Antibiotic Usage and Oxytetracycline Residue in African Catfish". Food Chemistry 5.3 (2013): 302309.

6. Guidi LR., et al. "A simple, fast and sensitive screening LC-ESIMS/MS method for antibiotics in fish". Talanta 163 (2017): 8593.

7. Raufu IA., et al. "Occurrence and antimicrobial susceptibility profiles of Salmonella serovars from fish in Maiduguri, subSaharah, Nigeria". Egyptian Journal of Aquatic Research 40.1 (2014): 59-63.

8. Akinwumi F and Adegbehingb K. "Microbiological Analysis of Three of Smoked Fish Obtained from the Ondo State, Nigeria". Food and Public Health 5.4 (2015): 122-126.

9. Tascini C., et al. "Reading and understanding an antibiogram". Italian Journal of Medicine 10.4 (2016): 289-300.

10. Imarhiagbe E., et al. "Antibiotic sensitivity pattern of microorganisms isolated from smoked and frozen fishes sold in Benin and Warri metropolis". Nigerian Journal of Biotechnology 31.1 (2016): 40-45.

11. Samuel M and Toba AS. "Occurrence and Antimicrobial Susceptibility Pattern of Bacteria Isolated from Gastrointestinal Tract of Fresh Water Fishes in Abuja, Nigeria". International Journal of Current Microbiology and Applied Sciences 6.4 (2017): 27352743.

12. Clinical and Laboratory Standards Institute. Performance Standards for Antimicrobial Susceptibility Testing; TwentyFourth Informational Supplement. CLSI document M100-S24 (ISBN 1-56238-897-5 [Print]; ISBN 1-56238-898-3 [Electronic]). Clinical and Laboratory Standards Institute, 950 West Valley Road, Suite 2500, Wayne, Pennsylvania 19087 USA (2014).

13. Akagha T., et al. "Prevalence and antibiogram of salmonella species and staphylococcus aureus in retail meats sold in awka metropolis, southeast Nigeria". International Journal of Biological and Pharmaceutical Research 6.12 (2015): 924-929.

14. Joanne M Willey., et al. Prescott's Microbiology Eighth Edition, 2011. Human Disases caused by bacteria, chapter 38, Foodborne and Water Disease (2011): 965-971. 
15. Verma S., et al. "Gentamicin as Oral Drug Delivery formulation". International Journal for Pharmaceutical Research Scholars 3.I-2 (2014): 199-207.

16. Ugwu MC., et al. "Antibiogram of Staphylococcus Aureus from Healthy School Pupils in Agulu, Southeastern Nigeria". International Journal of Research in Pharmacy and Biosciences 2.4 (2015): 5-9.

\section{Assets from publication with us}

- Prompt Acknowledgement after receiving the article

- Thorough Double blinded peer review

- Rapid Publication

- Issue of Publication Certificate

- High visibility of your Published work

Website: www.actascientific.com/

Submit Article: www.actascientific.com/submission.php

Email us: editor@actascientific.com

Contact us: +919182824667 